\title{
A környezeti számvitel fejlődésének áttekintése és összekapcsolása a vállalatok tevékenységének környezetvédelmi aspektusaival
}

\section{Reviewing the Development of Environmental Accounting and Linking it with the Environmental Aspects of Companies' Activities}

\section{Összefoglalás}

A környezeti számvitel területe elméleti és gyakorlati szempontból is egyre inkább fontos és aktuális kérdéskör. A szerző munkája során a környezeti számvitel történeti áttekintésére fókuszál. Alapvető cél a különböző aspektusokból történő megközelítésének és definiálásának kronologikus áttekintése, bemutatása. Ezen kívül a vállalatok környezetvédelmi és társadalmi tevékenységének átfogó ismertetése, végezetül a környezeti számvitel fejlődésével történő párhuzamba állítása. A környezet kérdését és a vállalatok üzleti kérdéseit összekapcsoló folyamat késztette arra a számvitel tudományát is, hogy a vállalatok környezeti és társadalmi hatásait meg- felelően kezelje, és erről - mint információs rendszer - az érdekeltek felé információt szolgáltasson. A szakirodalomban fellelhető források alapján, a környezeti számvitel fejlődése 5 szakaszra osztható fel, mely szakaszok (néhány év eltéréssel ugyan) jól párhuzamba állíthatók a vállalatok környezetvédelmi tevékenységének fejlődési fázisaival.

Journal of Economic Literature (JEL) kódok: D21, M14, M41, Q01, Q56

Kulcsszavak: környezeti számvitel, környezeti hatások, környezetvédelem, CSR

Bosnyák-Simon Nikolett, PhD hallgató, Pannon Egyetem (simon.nikolett@ gtk.uni-pannon.hu). 


\section{Summary}

The field of environmental accounting is becoming an increasingly important and current issue from both a theoretical and a practical point of view. The author's work focuses on a historical overview of environmental accounting. The basic goal is to chronologically review and present its approach and definition from different aspects, and beyond that, to provide a comprehensive description of the environmental and social activities of companies, and finally, to draw a parallel with the development of environmental accounting. After all, the process linking the issue of the environment with the business issues of companies has also led the science of accounting to properly manage the environmental and social impacts of companies and to provide information about this to stakeholders as an information system. Based on sources found in literature, the development of environmental accounting can be divided into 5 stages, which (albeit with a difference of a few years) can be well equated with the development phases of companies' environmental activities.

Journal of Economic Literature (JEL) codes: D21, M14, M41, Q01, Q56

Keywords: environmental accounting, environmental effects, environmental protection, CSR

\section{A KÖRNYEZETI SZÁMVITELI RENDSZER LEHATÁROLÁSÁNAK SZÜKSÉGESSÉGE}

A számvitel e lehatárolt területének - environmental accounting -, meghatározása igen szerteágazó. Tulajdonképpen a magyar fordítása nem is képes mindezt megragadni, ugyanis ebbe beletartozhatnak a nemzeti elszámolási rendszerek (GDP; makro szint), illetve az ahhoz kapcsolódó környezetvédelmi számlák (satelite accounts), a naturális mutatószámokkal dolgozó ökológiai számviteli rendszerek (ökológiai mérlegek), valamint a vezetői és a pénzügyi környezeti számvitel is (mikro szint) (Csutora-Kerekes, 2004). Ehhez kapcsolódóan, munkája érdemi, tartalmi részét megelőzően a szerző fontosnak tartja tisztázni, hogy mikro szinten, azaz a gazdálkodó szervezetek szintjén vizsgálja a környezeti számvitelt, mint a hagyományos számviteli rendszer egy részterületét.

Jelen tanulmány a környezeti számvitel fogalomrendszerével, illetve e terület elméleti hátterével kapcsolatban készült publikációkra alapozva igyekszik áttekinteni és összefüzni a környezeti számvitel fogalmának fejlődését, kezdve egészen a gyökerektől. Ám előtte lényeges röviden és átfogóan feltárni azt, hogy pontosan miért vált szükségessé a hagyományos számviteli rendszer keretén belül a környezeti számvitel lehatárolása.

A XXI. század egyik legnagyobb kihívását kétségtelenül a környezeti problémák jelentik (Kerekes et al., 1995), mely problémák mára már globális méreteket öltöttek. A tény vitathatatlan: a vállalatok tevékenységének környezetvédelmi aspektusai egyre inkább lényegessé, és sarkalatos üggyé válnak napjainkban. A környezetvédelem tehát kiemelt jelentőséggel bír, és számos tudományterületet érint. Valamennyi diszciplína felismerte már e tényt, és igyekszik megfelelően reagálni a környezetvédelemmel, tágabb értelemben a fenntarthatósággal, a fenntartható gazdasági növekedéssel kapcsolatban felmerült kihívásokra. E diszciplínák alól a számvitel sem képez kivételt, hiszen a társadalmi és környezeti számvitel fogalomrendszerének megjelenésével éppen ezekre a problémákra/kihívásokra hivatott reflektálni. Még mielőtt e részterületek feltérképezésre kerülnek, elsőként érdemes áttekinteni azt, hogy mi is az alapvető funkciója, szerepe a hagyományos számviteli rendszernek.

A piacgazdaság működéséhez nélkülözhetetlen, hogy a piac szereplői számára hozzáférhetően, döntéseik megalapozása érdekében a gazdálkodó szervezetek vagyoni, pénzügyi és jövedelmi helyzetéről és azok alakulásáról megbízható, pontos, lényeges és nem utolsó sorban objektív információk álljanak rendelkezésre. A számvitel alapvető feladata, hogy megbízható és valós összképet biztosító tájékoztatást nyújtson a szervezetek jövedelemtermelő képessé- 
géről, vagyonáról, vagyonának alakulásáról, pénzügyi helyzetéről és jövőbeli terveiről (2000. évi C. törvény).

A számvitel üzleti nyelvnek tekinthető (Riahi-Belkaoui, 2005), amely lehetővé teszi, hogy minden érdekelt féllel közölje a vállalatok teljesítményével kapcsolatos információkat (Eugénio et al., 2010). A társadalmi változások erőjeként is operacionalizálható, a cselekvések és eredmények láthatóvá és érthetővé tételének lehetőségén keresztül. Mint olyan, biztosíthatja azokat a mechanizmusokat, amelyek felelősséget és elszámoltathatóságot eredményeznek (Dillard et al., 2005).

A környezeti problémák fokozódásával a környezettudatosság az 1960-as és 1970es években növekedni kezdett (Dillard et al., 2005), melynek hatására a vállalatok társadalmi és környezeti felelőssége egyre inkább elötérbe került nemcsak az érdekelt felek, hanem a széles körben értelmezett nyilvánosság előtt is (Eugénio et al., 2010). Ennek érthető következményeként valamennyi érintett megfelelő információszolgáltatást várt el, és vár el napjainkban is a vállalatok környezeti tevékenysége kapcsán (is). Azonban a hagyományos számviteli rendszer - mint a vállalatok információs rendszere - e tekintetben jelentős hiányosságokkal küzd. Hiszen alapvetően nem szolgáltat megfelelő és elegendő információt a vállalatok környezetvédelmi tevékenységéről az érdekeltek, azaz a beszámoló adatait felhasználók számára. A hagyományos rendszert tekintve tehát, sem a pénzügyi sem a vezetői számvitel nem ad pontos információt arról, hogy a környezetet a vállalati tevékenység mennyiben sújtja, hogy a környezeti, társadalmi költség pontosan milyen magas (Ván, 2012b).

Ennek következtében megfogalmazódott a hagyományos számviteli rendszer keretén belül egy olyan terület/alrendszer kidolgozásának szükségessége, mely megfelelően tudja kezelni ezeket, és megfelelő információt is szolgáltat a gazdálkodó egységek társadalmi és környezeti hatásairól.

\section{A KÖRNYEZETI SZÁMVITEL FEJLŐDÉSI SZAKASZAI}

Habár a társadalmi és a környezeti számviteli gyakorlat pontos kezdetét nehéz meghatározni, számos szerző egyetért abban, hogy kialakulása valamikor az 1960-as és 1970-es évek közé datálható (Gray-Bebbington, 2001; Parker, 2005). Ugyanis már ebben az időben születtek olyan nézetek, melyek a hagyományos számviteli rendszer és a környezetvédelem összeegyeztetésének szükségességét emelték ki. Hiszen addig a hagyományos számviteli rendszer - ahogyan a szerző erre a fentiekben tett utalást - csak a pénzegységben kifejezhető hatások szempontjából vizsgálta, illetve mutatta be a vállalatot, biztosítva ezzel a döntéshozók számára a szervezetek összehasonlíthatóságát. Mára már azonban a környezeti kérdések a vállalatvezetők egyik legfontosabb problémájává váltak (Schaltegger-Burritt, 2010).

A tanulmány ezen részészében a szerző röviden egy átfogó képet kíván nyújtani arról, hogy pontosan hová is nyúlnak vissza a környezeti számvitel gyökerei, valamint, hogy az elmúlt évtizedek során milyen fejlődési fázisokon esett át. Ennek kapcsán, a környezeti számvitel kibontakozását, fejlődési tendenciáit feltáró szakirodalmi források alapján 5 fó fázis különíthető el (Ván, 2012a).

\section{Kibontakozás (1960-as évek)}

Két lényeges kiadványt kell megemlíteni a vizsgált témakörhöz kapcsolódva. Az egyik Howard R. Bowen (1953) könyve „Az üzletember társadalmi felelőssége" (Social Responsibilities of a Businessman) címmel. Ebben jelent meg elsőként a „vállalatok társadalmi felelőssége” fogalom. Míg a másik Rachel Carson (1962) „Néma tavasz" (Silent Spring) című műve, mely a környezetvédelem és a fenntarthatóság kapcsolatára fókuszált (Staib, 2005; Ván, 2012a).

Reagálva az új kihívásokra, ez a periódus a társadalmi számvitel iránti tudatosság növekedésének kezdetét, kibontakozását öleli fel, mely elsőként olyan területeken jelent meg, mint a 
vállalati etika és a társadalmi felelősség (Loew et al., 2004). A számvitel - a hagyományos számviteli rendszer hiányosságainak felismerése következtében - a szóban forgó kihívásokra kezdetben tehát az úgy nevezett társadalmi számvitel keretei közt reagált.

\section{Kezdeti idók (1970-es évek)}

A történelmi nézetek szerint a társadalmi számvitel az 1970-es évek folyamán vált aktív kutatási és gyakorlati területté (Gray-Bebbington, 2001). A téma iránti érdeklődés a környezeti terheléssel kapcsolatos aggodalmak fokozódásával kezdett egyre inkább erősödni. Ennek következtében, 1972-ben jelent meg a Római Klub „Növekedés határai” (The Limits to Growth) című jelentése, mely a gazdálkodó szervezetek tevékenységének káros következményeit tárgyalta (Meadows et al., 1972). Szintén ebben az évben, közel azonos témakörben rendezték meg a Stockholmi Konferenciát.

A társadalmi számvitel területén jelentősen megnövekedett az amerikai kutatók száma, akik többnyire a menedzsment területéről érkeztek. Ebben a periódusban (még kevésbé kiforrott) empirikus kutatásaik során elsősorban azzal a kérdéskörrel foglalkoztak, hogy a gazdasági társaságok milyen felelősséggel tartoznak a társadalomnak (Gray, 2002; Mullerat, 2010; Csáfor, 2009). Emellett már akkor is akadt olyan, a vizsgált témakör szempontjából leginkább releváns kutatás, mely a társadalmi felelősségvállalás és a profit közti kapcsolat vizsgálatára irányult. E kutatások megállapították, hogy bár közvetlen ok-okozati kapcsolat nem definiálható egyértelműen, ezek a tényezők nem függetlenek egymástól (Bowman-Haire, 1975).

Látható, hogy a kutatások alapvetően a vállalatok tevékenységének társadalmi vetületére fókuszáltak. Habár akkoriban a társadalmi számvitelrôl szóló tudományos írások még leginkább ad hoc jellegűek voltak, semmiképp sem tekinthetők lényegtelennek. A környezeti számvitel elkülönült fogalma nem jelent még meg, a környezeti tevékenységet érintő információk nyilvánosságra hozatala továbbra is a társadalmi számvitel keretén belül jelent meg. Fontos megemlíteni, hogy ebben az időszakban az American Accounting Association pozitívan támogatta a társadalmi (és a környezeti) számvitel fejlődését (Gray, 2002).

Mindazonáltal a '70-es évek végén, a kibontakozást követően viszonylag rövid ideig visszaesés mutatkozott a számvitel - hagyományos értelemben vett - szerepének megkérdőjelezését, ezáltal a társadalmi számvitel területe is háttérbe szorult. Ennek egyszerű oka, hogy a piaci szereplők még ekkor is leginkább a gazdasági jólétre fókuszáltak (Perego, 2005).

\section{Új hullám (1980-as évek)}

A rövid visszaesést követően, az 1980-as évek derekán egyre inkább elterjedtek a vállalatok etikai jelentései. Ennek következtében egy átfogó tudományos irodalom jelent meg, amelynek célja volt feltárni, hogy a multinacionális vállalatok (MNC-k) milyen mértékben számolnak be etikai, társadalmi és környezeti kérdésekről (Adams, 2004).

Az etikai kérdéseken túlmenően, ami a szervezetek tevékenységének környezeti aspektusait illeti, a '80-as évek súlyos környezeti katasztrófái, ipari szerencsétlenségei jelentősen felerősítették a környezeti kérdések iránti érdeklődést is, hiszen a vállalati tevékenységek ekkor már globális méreteket öltött környezeti problémákat idéztek elő. Egyértelműen rámutattak az emberi tevékenységek környezeti és társadalmi hatásaira, és előtérbe helyezték a gazdálkodó egységek környezetvédelmi tevékenységének szükségességét.

Mindezek hatására, az ENSZ Környezet és Fejlődés Világbizottság, más néven Brundtland-bizottság által 1987-ben közzétett „Közös jövőnk" című jelentés a gazdasági növekedés új korszakát sürgette, olyan növekedést, amely erőteljes, ugyanakkor társadalmilag és környezetileg egyaránt fenntartható (Gyulai, 2013:797). A fenntartható fejlődés olyan fejlődés, amely kielégíti a jelen szükségleteit, anélkül, hogy veszélyeztetné a jövő nemzedékek esélyét arra, hogy ők is kielégíthessék szükségleteiket (WCED, 1987). A Bizottság fenntartható fejlődésre vonatkozó 
akciótervét (Agenda 21) 1992-ben fogadtál el a Riói Egyezmény keretében. Ez alapvetően rákényszerítette a gazdálkodó egységeket arra, hogy felismerjék a környezeti menedzsment létjogosultságát, ezen túlmenően, mint a fenntartható fejlődés kulcselemét kezeljék (Madarasiné, 2009). Ezt követően a fenntartható fejlődés nemcsak a tudományos életben, hanem a gazdasági szereplők körében is kiemelt kérdéskörré vált, továbbá visszavonhatatlanul bekerült a köztudatba is.

Még inkább reflektálva a környezeti problémákra, ebben a periódusban már megkezdődik a környezeti számvitel fogalomrendszerének elkülönülése a társadalmi számviteltől. Ehhez kapcsolódóan, intenzív fejlődést mozdított elő e területen a specializált számviteli folyóiratok megjelenése is, úgy, mint az Accounting, Auditing and Accountability és a Journal of Accounting and Public Policy. A publikációk alapvető célja a számviteli jelentések fontosságának hangsúlyozása, valamint a környezeti információk hiteles bemutatása (Ván, 2012b).

Ebben a fejlődési szakaszban ugyan a környezeti számvitel elkülönült a társadalmi számviteltől, és egyre inkább előtérbe került, szinte autonóm területté vált (Eugénio et.al., 2010:288), egységes fogalomrendszer, keretelv a környezeti számvitelen belül még nem alakult ki ekkor (Gray et al., 1995b).

\section{Érésifázis (1990-es évek)}

Az 1990-es években a társadalmi hatások kimutatása és bevonása az éves jelentésbe már nem töltött be jelentős szerepet, helyettük immáron a környezeti információk domináltak (Gray, 2002). Következésképp a társadalmi számvitel egyre inkább háttérbe szorult, míg alrendszere, a környezeti számvitel egyre fokozottabb figyelmet kapott, kiemelt kutatási területté vált.

Egyre több kutató és szakember kezdett el foglalkozni a terület elméleti alátámasztottságának kidolgozásával. Alapvető cél volt a környezeti számvitel fő keretelveinek, modelljeinek a meghatározása. Elkington '90-es évek elején kidolgozott Triple Bottom Line koncepciója például a pénzügyi, társadalmi és környezeti dimenzióit integrálja, ezen kívül a fenntarthatóság és a vállalati érték közti kapcsolatot hangsúlyozza. Míg Mathews modellje a külső érdekelt felek számára dolgozott ki társadalmi szerződésre épülő pénzügyi, társadalmi és környezeti jelentési modellt (Perego, 2005).

Továbbá fontos megjegyezni, hogy ezzel egy időben más kutatási területek is jelentős hatást gyakoroltak a környezeti számvitelre. Ilyen terület többek közt az ellenőrzés és a stratégiai menedzsment. Utóbbi területén például egyre több környezeti ügyekhez kapcsolódó publikáció készült, hiszen egyre kiemeltebb téma a gazdálkodó szervezetek és a környezet közti kapcsolat fontossága (Mathews, 1997).

\section{Napjainkban (megközelitóleg a 2000-es évektôl)}

A nyilvánosság egyértelműen nagy érdeklődést mutat a társadalmi és környezeti kérdések iránt. Ez arra hívta fel a vállalatok figyelmét, hogy legyenek társadalmilag felelősségteljesebbek és jobban kezeljék környezeti hatásukat (Wilmshurst-Frost, 2000), valamint, tudatosítsák szervezetüknél, hogy ez hozzáadott értéket jelenthet számukra (Eugénio et al., 2010). Válaszul sok vállalat kifejlesztett környezetvédelmi vezetési és számviteli rendszereket, valamint fokozta társadalmi és környezeti nyilvánosságra hozatali gyakorlatát (Gray et al., 1995a, Guthrie-Parker, 1989).

Mindezek olyan kutatások növekedéséhez vezettek, amelyek az éves jelentésben közölt környezeti információkat elemzik, valamint iparági szinten vizsgálták azt, hogy ezek az információk befolyásolják-e a befektetői döntéseket a vizsgált szervezeteknél. Továbbá, szintén kiemelt kutatási témává vált a vállalat pénzügyi teljesítménye és a társadalmi felelősségvállalás közti kapcsolat feltárása (Mathews, 2000).

S míg a kutatások alapvetően a környezeti számvitel „termékére”, a környezeti jelentésekre és azok elemzésére fókuszáltak, addig többek közt például az ISO 14000 standard sorozat a vállalati környezeti vezetői rendszerekre, azok relevanciájára hívta fel a figyelmet (Madarasiné, 2009). 
Napjainkban, üzleti szempontból egyre inkább nő az érdeklődés az iránt, hogy a környezeti vonatkozású költségeket és bevételeket jobban megértsék, mérjék és kezeljék. Jelenleg az a legnagyobb kihívás a környezeti számviteli rendszerrel szemben, hogy a vállalatok integrálni tudják azt a mindennapi gyakorlatba (Ván, 2012b).

\section{A FOGALOMRENDSZER FEJLŐDÉSÉNEK ÁTTEKINTÉSE}

Ahogy azt eddig láthattuk, a fenntarthatóság, a vállalatok társadalmi felelősségvállalása, a gazdálkodó egységek tevékenységének társadalmi és környezeti hatásai iránti egyre szélesebb körű érdeklődés által támasztott kihívásokra reflektálva, a hagyományos számviteli rendszeren belül elsőként a társadalmi számvitel jelent meg, mint a hagyományos számviteli rendszer alrendszere, melyet a szakirodalom eleinte szinonimaként használt a környezeti számvitellel (Lamberton, 2005). A megfelelő fogalomhasználat sokáig a társadalmi és környezeti számvitel (social and environmental accounting) volt (Perego, 2005, Eugénio et al., 2010).

A tanulmány következő részében a szerző a társadalmi számvitel (social accounting), majd a környezeti számvitel (environmental accounting) fogalmát kívánja feltérképezni, továbbá a hagyományos számviteli rendszeren belüli elhelyezésüket, kapcsolatukat kívánja feltárni.

\section{A fenntarthatósági és a társadalmi számvitel meghatározása}

Mielőtt azonban a társadalmi számvitel fogalma kerülne górcső alá, a fogalomrendszer könnyebb áttekintése végett célszerű a fenntarthatósági számvitel területét, fogalmát is megismerni, és abból kiindulni. Átfogóan, a fenntarthatósági számvitel a számviteli rendszernek az a területe, amely méri, valamint elemzi a társadalmi és gazdasági fenntarthatóságot (Lamberton, 2005; Schaltegger-Burritt 2010). Ez tehát nagyon komplex részterület, amely a szervezet tevékenységének társadalmi, környezeti és gazdasági oldalát érinti, és egyben integrálja is eze- ket. Ebből kiindulva, a társadalmi számvitel és a környezeti számvitel ennek egy-egy további alrendszereként foghatók fel. Arra a kérdésre, hogy ezek pontosan milyen kapcsolatban álltak/állnak egymással a számviteli rendszeren belül, a következő meghatározások adnak választ.

A '90-es évek derekán néhány kutató úgy vélte, hogy mivel a társadalmi számvitel sok ember számára sok jelentéssel bír, meghatározása és elemzése nehéz lehet. Véleményük szerint a társadalmi számvitel a jelentéstétel kiterjesztésének tekinthető, amellyel a gazdálkodó szervezetek tájékoztatást nyújtanak a munkavállalókról, termékekről, szolgáltatásokról a társadalom számára, valamint megelőzik vagy csökkentik a környezet szennyezését. Ez alapján a környezeti kérdést - ekkor még - a társadalmi számvitel részének tekintették (Eugénio et al., 2010:288). Gray (2002) szerint a társadalmi számvitel új elszámolások megnyitását jelenti. Brown és társai ennél egzaktabb megfogalmazást adtak. Meglátásuk szerint a társadalmi számvitel egyfajta kommunikációs folyamatként értelmezhető, amely egy szervezet gazdasági tevékenységének a társadalmi és környezeti hatásait közvetíti a társadalom felé, és a fókuszban a vállalat átláthatósága van (Brown et al., 2006).

A fejlődési szakaszokra visszautalva néhány gondolat erejéig, a környezeti számvitel az 1960-1980 közötti időszakban egyértelműen a háttérben mutatott némi fejlődést, majd sokáig a társadalmi és környezeti számvitel megnevezést használták széles körben. Az „Új hullám” szakaszban különültek el egymástól e fogalmak, és a környezeti számvitel autonóm területté vált. E folyamatok következtében a környezeti számvitel első, egzakt meghatározásai az 1990es évek elején jelentek meg az áttekintett szakirodalomban. Azonban még mielőtt a környezeti számvitel definícióinak fejlődése kerülne ismertetésre, e három részterület hagyományos számviteli rendszeren belüli kapcsolatrendszerének áttekintése kap helyet a tanulmány ezen részében.

Az értelmezések alapján elmondható, hogy a fenntarthatósági számvitel tekinthető a legbő- 
vebb kategóriának, ami integrálja a társadalmi számvitelt. Végezetül a környezeti számvitel a társadalmi számvitel alkategóriája, amely a vállalat és a természeti környezet közti kapcsolatot integrálja (Eugénio et al., 2010). Hasonló formában megfogalmazva, Adams is úgy vélekedik, hogy a környezeti jelentések egyértelműen az etikai jelentések részhalmaza, és általában a társadalmi jelentések részhalmazának is tekinthetők, de mint a társadalmi és etikai jelentések leggyakoribb típusa, külön címkét igényel (Adams, 2002).

A fentiek alapján, e három fogalom hagyományos számviteli rendszeren belüli kapcsolatrendszerét az 1. számú ábra szemlélteti.

Az eddigiek alapján láthattuk, hogy mikor jelent meg, illetve hogyan bontakozott ki a társadalmi és környezeti számvitel területe. A következőkben már kizárólag a környezeti számvitel fogalmára, illetve annak időbeli fejlődésére fókuszál a szerző.

\section{Környezeti számvitel - a tudományos, kutatói megközelités definicióinak fejlödése}

A környezeti számvitel a '80-as években különült el egzakt módon a társadalmi számvitel fogalomrendszerétől és vált fokozatosan a hagyományos számvitelen belül egyre jelentősebb területté. Intenzív fejlődés az „Érési fázis”-ban bontakozott ki, amikor is már jóval több kutatás irányult a környezeti számvitel területének feltérképezésére. A szakma ugyanis felismerte az elméleti alátámasztottság égető szükségességét (Ván, 2012b), és ettől kezdve foglalkozott mélyebben a környezeti számvitel definíciójával. Az idők folyamán többféle megközelítésben, több definíciója született, mivel tartalmának vizsgálatával és e tevékenység ideológiai helyének meghatározásával szimultán több kutató, szakember is foglalkozott.

Egy korai definíciója Senge nevéhez köthető, aki a hagyományos számvitelből kiindulva úgy közelítette meg a környezeti számvitel fogalmát, hogy az szigorú értelemben véve csak azokat a konkrét kötelezettségek és kiadások kimutatását célozhatja meg, melyek bírósági, jogi ítéletekből vagy megelőző tevékenyéghez kapcsolódó kiadásokból erednek (Senge, 1993).

Meghatározásában ő egyértelműen a kötelezettségeket és kiadásokat azonosította a környezeti számvitellel. Ehhez kapcsolódóan fontos megjegyezni, hogy az üzleti gyakorlatban

\section{1. ábra: A környezeti számvitel elhelyezése a hagyományos számviteli rendszerben}

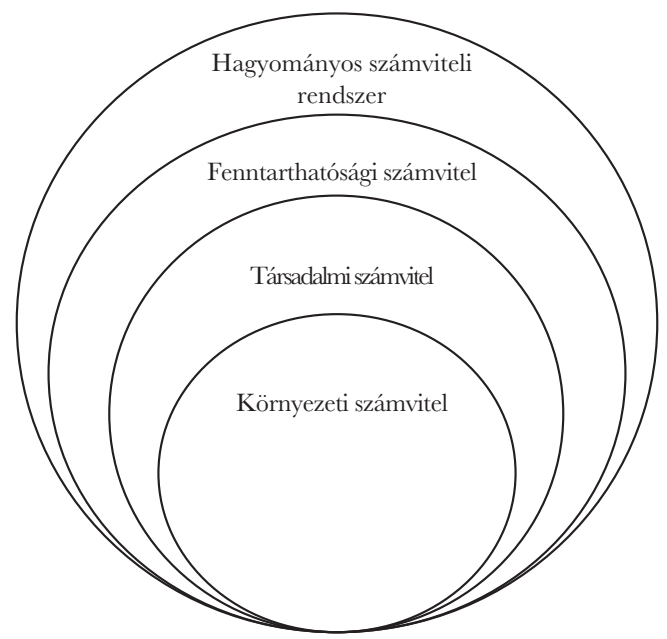

Forrás: Saját szerkesztés Adams (2002), Eugénio et al. (2010) alapján 
hosszú ideig jellemző volt, hogy a menedzsment a környezeti számvitel területét pusztán csak a kötelezettségekkel, illetve a költségekkel kötötte össze. Ám kutatások mára már bizonyították, hogy a környezeti hasznok kimutatása is igen releváns tényező (Ván, 2012b), valamint, hogy a környezeti tevékenységek rendszerezett és hiteles kommunikálása a versenyképesség növelésének egy fontos tényezője lehet.

Schaltegger és szerzőtársa e terület feladatára helyezik a hangsúlyt. Véleményük szerint a környezeti számvitel a számvitel egyik ága, amely azokat a tevékenységeket, módszereket és rendszereket foglalja magában, amelyek egy meghatározott gazdasági rendszer környezetvédelmi problémáit vagy környezetvédelmi tevékenység gazdasági hatásait tartják nyilván, elemzik, jelentésbe foglalják (SchalteggerBurritt, 2000).

Nagyon átfogó meghatározást dolgoztak ki, amely a szerző véleménye szerint kiválóan öszszegzi e rendszer működésének alapvető elveit, feladatait. Olyan, a környezeti kérdések kezelésének rendszereként határozták meg a környezeti számvitelt, amelyben egyaránt benne rejlik a környezeti információk vállalaton belüli feldolgozása, valamint a piaci szereplőknek (kifelé) történő kommunikálása (Madarasiné, 2009). Azaz, a környezeti számvitel pénzügyi és vezetői számviteli rendszerének szerepét egyaránt hangsúlyozzák. (A hagyományos számviteli rendszer dichotómiája tehát ebben az alrendszerben is jelen van.) Látható, hogy itt már a társadalmi hatás egyértelműen háttérbe szorult, és helyette a környezetvédelmi problémák, illetve a vállalkozás által folytatott tevékenység környezetvédelmi aspektusai kerültek fókuszba. Továbbá fontos megemlíteni, hogy a környezeti számvitel hagyományos számviteli rendszeren belüli kiemelt szerepének hangsúlyozása e szerzőpáros nevéhez köthető. Rámutattak arra, hogy a hagyományos számviteli rendszernek egyrészt a társadalmi hatások mérésében, másrészt a környezetvédelem területén jelentős hiányosságokkal rendelkezik.
A '90-es évek derekán a performatív megközelítés dominált, melynek lényege, hogy a szóban forgó fogalom, tevékenység - jelen esetben a környezeti számvitel - értelmezése nem a definíciókon, szabályokon alapul, hanem a felhasználó értelmezésétől függ. E megközelítésben értelmezte Perry-Sheng (1999) szerzőpáros. Meglátásuk szerint a vállalkozások őszinte törekvése környezetvédelmi teljesítményüket meghatározó kérdések kommunikálására.

Bebbington és szerzőtársai (1999) a számvitel új formáinak kialakulását látták e terület kidolgozása mögött. Munkájukban úgy fogalmaztak, hogy a környezeti számvitel az elméleti számvitel egyik központi részévé vált.

Korábban már utalt rá a szerző, hogy kialakulásakor és azt követően is hosszú ideig a menedzsment az üzleti gyakorlatban pusztán a költségekkel, illetve a kötelezettségekkel azonosította a környezeti számvitel fogalomrendszerét. Azonban, a '90-es évek végén, a 2000-es évek elején egyes kutatók az éves jelentésben közölt környezeti információkat, az információk befektetői döntésekre gyakorolt hatását is elemezni kezdték. Ennek kapcsán Beets és Souther eredményei azt igazolták, hogy a vállalati környezeti jelentések értékes hatást gyakorolhatnak a befektetési döntésekre is (Beets-Souther, 1999). E kutatási eredményekre reflektálva, e jelentések nemcsak arra ösztönzik a vállalatokat, hogy fegyelmezettebbek legyenek környezeti teljesítményükkel kapcsolatban, ami egyben környezeti kockázatukat is csökkenti, hanem ésszerű üzleti megfontolást is takar, hiszen pozitív PR-t teremt, továbbá a jó ,zöld” jelentések megkülönböztető szerepet adnak a vállalatoknak (Kolk, 2000).

Reyes (2002) a környezeti számvitelt a hagyományos számviteli rendszer olyan részterületeként írja le, amely azokkal a tevékenységekkel, módszerekkel és rendszerekkel foglalkozik, amelyek feljegyzik, elemzik és bemutatják (közzéteszik) egy meghatározott gazdasági rendszer (egy cég vagy egy nemzet) környezettel kapcsolatos pénzügyi hatásait. 
Ez idő tájt, a 2000-es évek elején találkozhatunk a hazai szakirodalomban a környezeti számvitel fogalmával. Csutora (2001) úgy fogalmaz, hogy e területnek a feladata egyrészt a környezetvédelem pénzügyi vonzatainak kimutatása és vizsgálata, másrészt a gazdasági tevékenység bizonyos környezeti tényezőkre gyakorolt hatásainak elemzése. A hazai forrásokban gyakran a környezeti elszámolások országos (makro) és vállalati (mikro) szintjének definiálásához kötik a meghatározását. Pál (2003) megfogalmazása kapcsán ennek a területnek alapvető feladata egyrészt a gazdálkodás hatására a természeti erőforrásokban bekövetkezett változások számbavétele (makro szint) másrészt a környezeti költségek és okozóik feltárása (mikro szint).

Szintén a 2000-es évek elején, nemzetközi szinten, a fenntartható vállalati tevékenység aspektusából vizsgálva a szakemberek úgy fogalmaztak, hogy a környezeti számvitel elóállítja, elemzi, valamint felhasználja a pénzügyi és nem pénzügyi információkat annak érdekében, hogy optimalizálja a vállalat környezeti és gazdasági teljesítményét a fenntartható üzletmenet elérése érdekében (Bennett et al., 2003). E megközelítésben már megjelenik - mint általános számviteli alapelv - a vállalkozás folytatásának elve, melynek lényege, hogy a beszámoló elkészítésekor és a könyvvezetés során abból kell kiindulni, hogy a gazdálkodó a belátható jövőben is fenn tudja tartani múködését, folytatni tudja tevékenységét, nem várható a működés beszüntetése vagy bármilyen okból történő jelentős csökkenése (2000. évi C. törvény). Emellett fontos kiemelni a stratégiai tervezésnek, mint a stratégiai menedzsment kiemelt területének a megjelenését is.

Kósi-Valkó szerzőpáros néhány évvel később a környezeti számvitelt úgy definiálja, mint a számviteli információs rendszeren belül a szervezet működése során a környezeti tényezőkről nyert, rendszerezett - a döntés előkészítéshez és az ellenőrzéshez megfelelő formában megjelenített - fizikai, illetve monetarizált információk halmaza (Kósi-Valkó 2006:94). Az ő meghatározásuk alapvetően a környezeti számvitel vállalaton belüli információs szerepét emeli ki. Azaz a vezetői információs szerepére fókuszál.

Korábban Schaltegger definíciójában egyaránt benne rejlett a környezeti információk vállalaton belüli feldolgozása, és a piaci szereplőknek történő kommunikálása is. Néhány évvel később, azonban már ők is a környezeti vezetői számvitel területére összpontosítottak alapvetően. Egy bővített fogalmat definiáltak, hiszen a környezeti vezetői számvitel területét további két részterületre bontották fel. Úgy fogalmaztak, hogy a környezeti számvitel olyan kutatást, gyakorlatot testesít meg, ami arra irányul, hogy egy szervezetnek milyen hatása van a természeti környezetre, illetve a környezetnek a vállalatra. Mindez értelmezhető és kifejezhető pénzügyi és fizikai egységben is (Schaltegger-Burritt, 2010). Azaz, mind monetáris, mind fizikai mérési rendszerrel egészíti ki a számviteli rendszert, így napjainkban megkülönböztethető a monetáris és a fizikai környezeti vezetői számvitel.

A fentiek összegzéseként, valamint a könynyebb áttekinthetőség céljából a 2. számú ábra a környezeti számvitelen belül elkülöníthető alrendszereket szemlélteti.

Átfogóan, lényegét tekintve tehát azt mondhatjuk, hogy a környezeti számvitel a számvitelnek az a lehatárolt területe, amely a környezeti problémákra/kihívásokra hivatott reflektálni. Egy jóval szűkebben értelmezett területe a számviteli rendszernek, ugyanakkor mégis túlmutat annak lényegi feladatkörén. A számviteli rendszernek ez az ága foglalkozik vállalati szinten a környezeti problémák kezelésével, mely lényegében a hagyományos számviteli rendszert kiegészítő alrendszernek tekinthető. A környezeti számvitel a környezeti teljesítmény mérését segíti, amellyel szoros kapcsolatban áll a vállalatok társadalmi szerepe (Ván, 2012b).

\section{A KÖRNYEZETI SZÁMVITEL FELÉRTÉKELŐDÖTT SZEREPE A VÁLLALATOK ÉLETÉBEN}

A környezeti számvitel hagyományos számviteli rendszeren belüli funkciójának, fejlődési sza- 


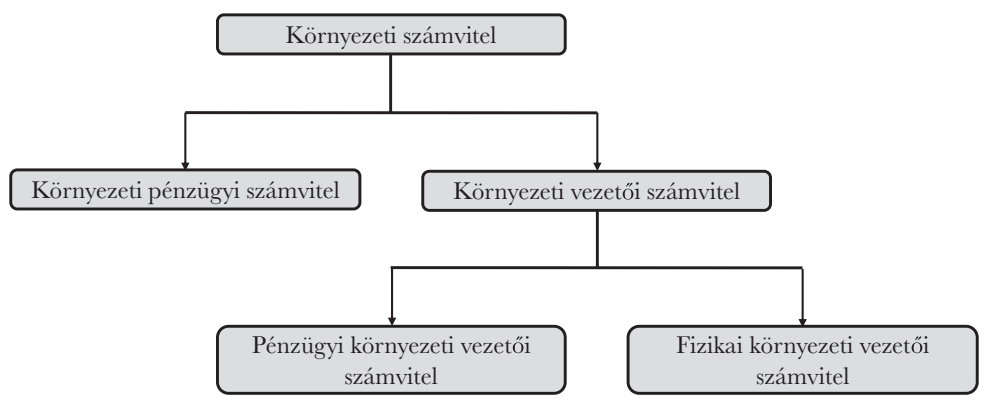

Forrás: Saját szerkesztés Madarasiné (2009), Schaltegger-Burritt (2010) nyomán

kaszainak, illetve különböző megközelítéseinek bemutatását követően, ebben a részben a vállalatok működésében betöltött egyre fontosabb szerepére szeretne rámutatni a szerző.

Vitathatatlan, hogy a vállalatok - a környezethez és a társadalomhoz füződő kapcsolatuk tekintetében - sosem voltak önálló szervezetek. Hiszen egyrészt mindenkor reagáltak a komplex és összefonódó környezetre, és az onnét származó információkra, de ugyanakkor függenek is attól (Staib, 2005). A gazdaság, a társadalom és a természeti környezet viszonya, a közöttük lévő kölcsönhatás rendkívül összetett. (Németh, 2006).

\section{Fenntarthatóság és/vagy gazdasági növekedés?}

A fenntarthatóság alapvetően az antropocentrizmus és az ökocentrizmus ellentétes nézeteiben gyökerezik. E két nézet kompromisszumának tekinthető (Staib, 2005), mely az elmúlt néhány évtizedben, a Brundtland-jelentés kiadása óta vált lényeges kérdéskörré az üzleti életben is. A fenntartható fejlődés biztosítja a jelen szükségleteinek kielégítését anélkül, hogy a jövő generáció szükségleteinek kielégítését veszélyeztetné (WCED, 1987).

A környezet, a társadalom és a gazdaság közötti egyensúly elérése lényeges tehát ahhoz, hogy a jelen szükségletei úgy teljesüljenek, hogy ne veszélyeztessék a jövő generációk esélyét arra, hogy ők is kielégíthessék szükségleteiket.
A fenntartható fejlődés, mint cél a fenntarthatóság e három pillérének egyensúlyával érhetô el. Mára társadalmi elvárások alakultak ki a fenntartható fejlődés, az átláthatóság és az elszámoltathatóság iránt, az egyre szigorodó jogszabályok mellett, és ez arra készteti a szervezeteket, hogy hozzájáruljanak a fenntarthatóság környezeti pilléréhez (MSZ EN ISO 14001:2015).

A tudományos életben számos elmélet született már a környezetvédelem társadalmi és gazdasági összefüggéseinek vonatkozásában. Ami a fenntarthatóság és annak gazdasági növekedéshez füződő viszonyát illeti, a teóriák két nagy csoportja állítható szembe egymással. Az egyik csoport képviselői úgy vélik, hogy a gazdasági növekedés a fenntarthatóság bizonyos korlátját jelenti, míg ezzel szemben a másik csoport épp ellenkezően ítéli meg. Németh (2006) a vállalatok környezetvédelmi tevékenységét vizsgálta a versenyképességben. Kutatási eredményei tükrében azt a következtetést vonta le, hogy azon gazdálkodó egységek, melyek tudatosan hangsúlyt helyeznek a környezeti és társadalmi tevékenységekre, növelni tudják versenyképességüket. A környezetvédelem, a gazdasági verseny és a vállalati versenyképesség között erősödő, összetett kölcsönhatás áll fenn (Németh, 2006).

A szerző maga is az utóbbi állásponttal ért egyet. Lényegében a vállalatok szükségletévé vált, hogy reagáljanak a fokozódó környezeti 
problémákra, és fontos szerepet töltsenek be a környezeti hatások csökkentésében. Mind belső, mind külső tényezők lényegében kényszerítik erre. Egyrészt a belső érdekeltek arra számítanak, hogy vállalatuk környezettudatos módon végzi tevékenységét. Másrészt, külső tényezőként, jelen van a környezetvédelmi szabályozás, azaz a jogszabályi előírásoknak való megfelelés kényszere, valamint a piaci partnerek elvárásai, aktivista csoportok tevékenysége, és nem utolsó sorban a megváltozott társadalmi elvárások (Staib, 2005).

\section{A vállalat külső befolyásoló csoportjai}

A fentiekhez kapcsolódóan, reflektálva a külső érdekelt felekre, néhány gondolat erejéig mindenképp megemlítendő, hogy e kategórián belül mely befolyásoló csoportokhoz köthető a környezeti információk megjelenítésének szükségessége és igénye. Ezeket a csoportokat szemlélteti

\section{a 3. számú ábra.}

Látható, hogy számos érdekelt fél gyakorol hatást a vállalatok környezetvédelmi tevékenységére. Ezek közül kiemelendő a fogyasztók, tágabb értelemben a társadalom csoportja. Valószínúleg ez tekinthető a legfontosabb ösztönző tényezőnek a vállalatok számára napjainkban.

A társadalmi - és szűkebb értelemben véve a fogyasztói - preferenciák az utóbbi időszakban ugyanis lényegesen átalakultak. A zöld fogyasztókkal a fogyasztók egy olyan köre alakult ki a piacon, amely többek közt olyan termékeket keres, melyeket újból felhasználható anyagokba csomagolnak, továbbá környezetbarát termékekhez, illetve márkákhoz ragaszkodik (Elkington et al., 1990).

Így a számvitel mellett a marketing is egyértelműen azon diszciplínák közé tartozik, amely megfelelően igyekezett reagálni a környezetvédelem, és tágabb értelmezésben a fenntartható gazdasági növekedés kihívásaira. Mivel a világ-

\section{3. ábra: A vállalat külsó befolyásoló csoportjai}

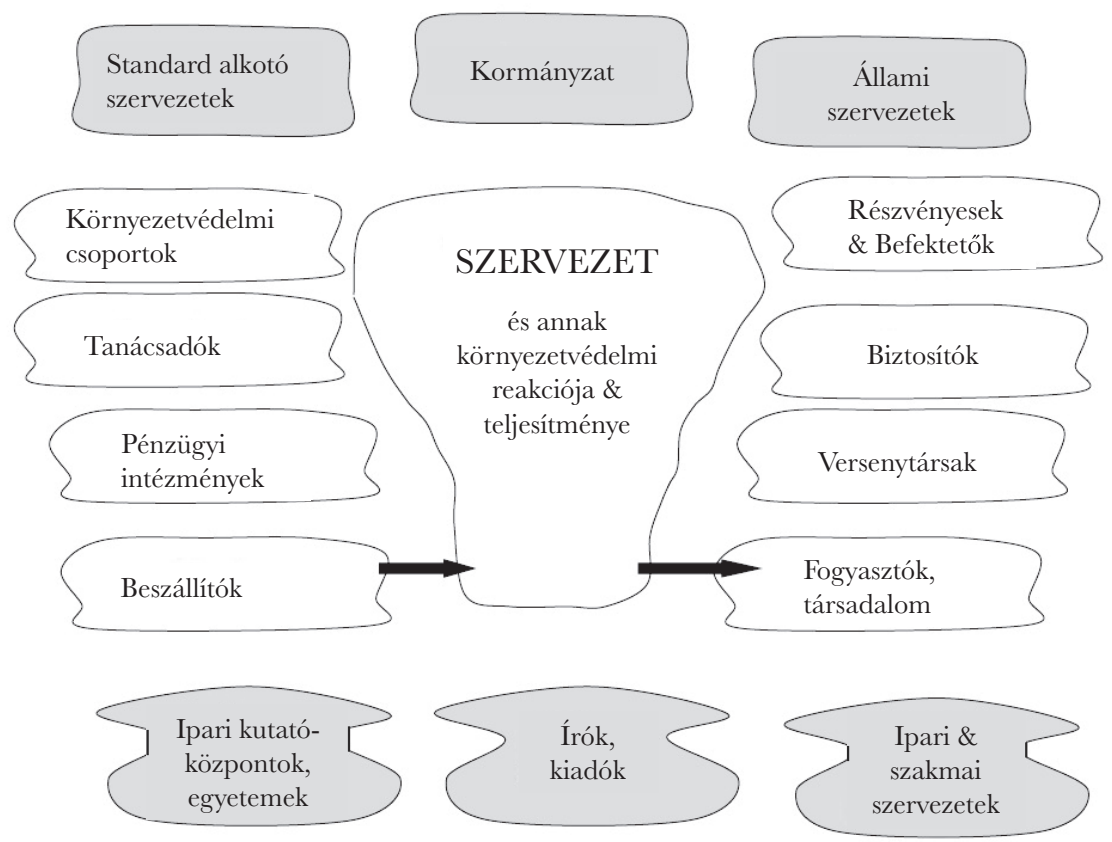

Forrás: Saját szerkesztés Hoffman (2001), Staib (2005) nyomán 
méretű kompetitív marketing alapvető tényezői közé tartozik a fogyasztói trendek és elvárások alapos kiismerése, így bizonyíthatóan nagy volt a jelentősége a zöld fogyasztói értékek és viselkedések kiismerésének, és az arra való reagálásnak. A marketingtudomány életre hívta a „zöld” marketing területét (Staib, 2005).

Mindezek tükrében a szerző egyértelműen egyetért azzal az állásponttal, miszerint a gazdálkodó egységeknek fel kell ismerniük ezeket a megváltozott preferenciákat, elvárásokat, és rá kell ébredniük arra, hogy a környezetre gyakorolt hatásuk, illetve a környezeti tevékenységük rendszerezett és következetes bemutatása hosszú távon egészen egyszerűen nem kerülhető el, és ezek bemutatása a legitimációt, illetve a versenyképességet támogató eszközzé válhat számukra (Madarasiné, 2009).

\section{ÖssZegzÉs}

A vállalatok felelőssége a kezdetektől nagyobb annál, hogy tulajdonosai számára nyereséget termeljenek (Staib, 2005). A '60-es években mutatkozó környezeti problémák, a későbbi környezeti katasztrófák, ipari szerencsétlenségek (1974, Seveso; 1984, Bophal) minden kétséget kizáróan rávilágítottak arra, hogy a vállalatok milyen jelentős hatással bírnak és mekkora felelősséggel rendelkeznek a környezetük és a társadalom iránt. Ennek következtében a tudományos élet képviselői mellett a nyilvánosság figyelme is fokozatosan a környezeti problémákra irányult.

A környezeti és társadalmi aspektusok fontossá válásával a vállalatok szükségletévé vált, hogy reagáljanak a fokozódó környezeti problémákra, és fontos szerepet töltsenek be a környezeti hatások csökkentésében. Mind belső, mind külső tényezők lényegében kényszerítették erre. Ehhez kapcsolódóan Frankel (1998) négy szakaszra osztotta fel a vállalatok környezetvédelmi tevékenységének korszakait. Ezeket a szerző - munkája összegzéseként - a környezeti számvitel már fentebb ismertetett fejlődési szakaszaival állítja párhuzamba, melyet az 1 . táblázat szemléltet.

Jól látható, hogy néhány év eltéréssel ugyan, de a vállalatok környezetvédelmi tevékenységé- nek, valamint a környezeti számvitel területének fejlődési szakaszai jól párhuzamba állíthatók. A számvitel már a kezdetekben felismerte a környezetvédelem és ezzel együtt a vállalatok környezetre gyakorolt hatások elemzésének fontosságát, így már a vállalatok környezeti és társadalmi aspektusok fontossá válásával egy időben reagált az új kihívásokra.

A fejlődési szakaszok áttekintése során láthattuk, hogy a szervezetek környezeti és a társadalmi hatásokat is figyelembe vevő információigénye a számvitel egy külön fejlődési területének tekinthető (Ván, 2012a). A '60-as években fejlődésnek indult a társadalmi és a környezeti számvitel, mely közvetlenül az 1960-as és 1970-es évek üzleti és társadalmi felelősségvállalási kérdésköréből nőtt ki, dominánsan vezetői felhangokkal és aggodalmakkal (Gray, 2002), és melyet sokáig a szakirodalom szinonimaként használt (Lamberton, 2005). A megfelelő fogalomhasználat a társadalmi és környezeti számvitel (social and environmental accounting) volt korábban (Perego, 2005, Eugénio et al., 2010).

Közülük a környezeti számvitel 1960-1980 között egyértelműen a háttérben mutatott némi fejlődést, a társadalmi számvitel alrendszereként. Majd az „Új hullám” szakaszban a két fogalom elkülönül egymástól, és a környezeti számvitel területén intenzív fejlődés bontakozott ki. E folyamatok következtében a környezeti számvitel első, egzakt meghatározásai az 1990-es években jelentek meg. Majd ezt követően már jóval több kutatás irányult a környezeti számvitel területének feltérképezésére mind elméleti, mind gyakorlati kérdéseit illetően.

Jelen tanulmányban alapvetően kronologikus sorrendben haladva kerültek bemutatásra a tudományterület kiemelkedő kutatóinak meghatározásai. A fogalom fejlődésének áttekintése kapcsán láthattuk, hogy a kutatók többsége tartalmi oldaláról definiálta a környezeti számvitelt.

Az ismertetett definíciók közül a Schaltegger és szerzőtársa definíciójára érdemes visszautalni néhány gondolat erejéig. A szerző meglátása szerint nagyon jól megragadták és összegezték a környezeti számvitel területének alapvető lényegét. Olyan, a környezeti kérdések kezelésének 
1. táblázat: A vállalatok környezeti tevékenységének és a környezeti számvitel fejlódésének szakaszai

\begin{tabular}{|c|c|c|c|c|}
\hline \multicolumn{2}{|c|}{$\begin{array}{c}\text { Vállalatok környezetvé- } \\
\text { delmi tevékenységének } \\
\text { szakaszai }\end{array}$} & \multicolumn{2}{|c|}{$\begin{array}{l}\text { Környezeti számvitel } \\
\text { fejlődésének szakaszai }\end{array}$} & \multirow{2}{*}{ A periódus fóbb jellemzői } \\
\hline $\begin{array}{l}\text { Szakasz } \\
\text { megneve- } \\
\text { zése }\end{array}$ & $\begin{array}{l}\text { Szakasz } \\
\text { kezdete }\end{array}$ & $\begin{array}{l}\text { Szakasz } \\
\text { megneve- } \\
\text { zése }\end{array}$ & Időszak & \\
\hline \multirow[t]{2}{*}{ Első } & \multirow[t]{2}{*}{1962} & $\begin{array}{l}\text { Kibontako- } \\
\text { zás }\end{array}$ & 1960-as évek & $\begin{array}{l}\text { Carson (1963) „Néma tavasz” (Silent } \\
\text { Spring) című múvének megjelenése. } \\
\text { A társadalmi számvitel iránti érdek- } \\
\text { lődés kibontakozása. }\end{array}$ \\
\hline & & Kezdeti idők & 1970-es évek & $\begin{array}{l}\text { Kevésbé kiforrott empirikus kutatá- } \\
\text { sok a társadalmi számvitel területén. } \\
\text { Majd néhány éves visszaesés. }\end{array}$ \\
\hline Második & 1984 & Új hullám & 1980-as évek & $\begin{array}{l}\text { A környezeti katasztrófák és az ipari } \\
\text { szerencsétlenségek kapcsán (pl. } 1984 \\
\text { Bhopal, } 1989 \text { Exxon Waldez) a vál- } \\
\text { lalatok felelősségének kérdéskörének } \\
\text { előtérbe kerülése. } \\
\text { A fenntartható fejlődés fogalmának } \\
\text { elterjedése az üzleti gyakorlatban. } \\
\text { A környezeti számviteli rendszer } \\
\text { jelentőségének fokozódása. }\end{array}$ \\
\hline Harmadik & 1992 & Érési fázis & 1990-es évek & $\begin{array}{l}\text { A környezetvédelmi szabályozás } \\
\text { térnyerése számos országban. } \\
\text { A környezeti számvitel elméleti } \\
\text { hátterének, a fő keretelveknek a } \\
\text { kidolgozása. }\end{array}$ \\
\hline Negyedik & $\begin{array}{l}\text { 2004-től } \\
\text { napjainkig }\end{array}$ & Napjainkban & ２000-től & $\begin{array}{l}\text { Modellek, keretrendszerek kiépítése. } \\
\text { Fő kérdéskör a környezeti számvitel } \\
\text { mindennapi gyakorlatba történő } \\
\text { integrálása. }\end{array}$ \\
\hline
\end{tabular}

Forrás: Saját szerkesztés Frankel (1998) és Ván (2012a) nyomán

rendszereként határozták meg ezt az alrendszert, amelyben egyaránt benne rejlik a környezeti információk vállalaton belüli feldolgozása, valamint a külső érdekeltek felé történő kommunikálása. Azaz, a környezeti számvitel pénzügyi és vezetői számviteli rendszerének szerepét egyaránt hangsúlyozzák.
Napjainkban a környezeti információk feldolgozásának és megjelenítésének módszerei, módjai, illetve a jelentős környezeti kezdeményezések tartalmai és jelentési struktúráik mind abba az irányba mutatnak, hogy a gazdálkodó szervezetek környezettel kapcsolatos tevékenységének, működésének információs rendszere, 
kommunikációs eszköze - azaz a környezeti számvitel - a számvitel vezetői számviteli ágához rendelhetők, mint annak egyik alrendszere (Madarasiné, 2009).

Ettől függetlenül természetesen a gazdálkodó egységek működésében a számvitel rendszer ténylegesen csak abban az esetben tudja betölteni fó funkcióját, ha két alrendszere, azaz a vezetői és pénzügyi számvitel egymásra épül és egymást kiegészíti. Hiszen ez biztosítja valamennyi érdekelt fél, befolyásoló csoport megfelelő tájékoztatását.

A szerző, munkája lezárásaként David Attenborough, brit természettudós, dokumentumfilmes, az ismeretterjesztő televízióműsorok egyik úttörőjének szavait idézi: „A földi élet jövője attól függ, hogy képesek vagyunk-e cselekedni. Sokan egyénileg is megtesznek minden tőlük telhetőt, ám valódi sikert csak akkor érhetünk el, ha gyökeres változások mennek végbe a társadalomban, a gazdaságban és a politikában" (ecolounge.hu).

\section{FELHASZNÁLT IRODALOM}

Adams, Carol A. (2004): The ethical, social and environmental reporting-performance portrayal gap. Accounting, Auditing and Accountability Fournal, vol. 17., no. 5., 731-757.

Bebbington, Jan - Gray, Rob - Owen, David (1999): Seeing the wood for the trees: taking the pulse of social and environmental accounting. Accounting Auditing and Accountability fournal, vol. 12., no. 1., 47-51.

Beets, S. Douglas - Souther, Christopher C. (1999): Corporate environmental reports: the need for standards and an environmental assurance service. Accounting Horizons, vol. 13., no. 2., 129-145.

Bennett, Martin - Rikhardsson, Pall M. - Schaltegger, Stefan (szerk.) (2003): Environmental Management Accounting - Purpose and Progress. Kluwer Academic Publishers, Netherlands

Bowen, Howard R. (1953): Social Responsibilities of a Businessman. New York, Harper

Bowman, Edward H. - Haire, Mason (1975): A strategic posture toward corporate social responsibility. Calfornia Management Review, vol. 18., no. 2., 49-58.

Brown, Darrell - Dillard, Jesse - Marshall, R. Scott (2006): Triple Bottom Line: A business metaphor for a social construct. Departament d'Economia de l'Empresa, Universitat
Autónoma de Barcelona, Spain

Carson, Rachel (1962): Silent Spring. Houghton Mifflin Co.

Csáfor Hajnalka (2009): Vállalatok társadalmi felelösségvállalása, regionális vizsgálat az Észak-magyarországi Régióban. Doktori értekezés, Budapest

Csutora Mária (2001): A vállalati környezetvédelmi költségek számbavétele. Tisztább Termelési Kiskönyvtár III, Budapest

Csutora Mária - Kerekes Sándor (2004): A környezetbarát vállalatirányítás eszközei. KJK KERSZÖV, Budapest

Dillard, Jesse - Brown, Darrell - Marshall, R. Scott (2005): An environmentally enlightened accounting. Accounting Forum, 29, 77-101.

Elkington, John - Hailes, Julia - Makower, Joel (1990): The Green Consumer. Penguin, New York

Eugénio, Teresa - Lourenco, Isabel - Morais, Ana Isabel (2010): Recent developments in social and environmental accounting research. Social Responsibility fournal, vol. 6., no. 2., 286-305.

Frankel, Carl (1998): In Earth's Company, Business, Environment and the Challenge of Sustainability. New Society Publishers, Canada in Staib, Robert (2005): Environmental Management and Decision Making for Business, PALGRAVE MACMILLAN

Gray, Rob (2002): The social accounting project and Accounting Organizations and Society Privileging engagement, imaginings, new accounting and pragmatism over critique? Accounting, Organizations and Society, 27, 687-708.

Gray, Rob - Bebbington, Jan (2001): Accounting for the Environmental. Sage Publications, London

Gray, Rob - Kouhy, Reza - Lavers, Simon (1995a): Corporate social and environmental reporting: a review of the literature and a longitudinal study of UK disclosure. Accounting, Auditing and Accountability Journal, vol. 8., no. 2., $47-77$.

Gray, Rob - Kouhy, Reza - Lavers, Simon (1995b): Methodological themes: constructing a research database of social and environmental reporting by UK companies. Accounting Auditing and Accountability fournal, vol. 8., no. 2., 78-101.

Gyulai Iván (2013): Fenntartható fejlődés és fenntartható növekedés. Statisztikai Szemle, vol. 91., no. 8-9., 797-822.

Hoffman, Andrew J. (2001): From Heresy to Dogma, An Institutional History of Corporate Environmentalism, Stanford, California: Stanford Univerity Press in Staib, Robert (2005): Environmental Management and Decision Making for Business, PALGRAVE MACMILLAN

Kerekes Sándor - Dennis, Rondinelli - Vastag Gyula (1995): A vállalatok környezeti kockázatai és a vállalat- 


\section{Tudományos mühely}

vezetők felelőssége. Közgazdasági Szemle, vol. 17., no. 9. , 882-895.

Kolk, Ans (2000): Green reporting. Harvard Business Review, vol. 78., no. 1., 15-16.

Kósi Kálmán - Valkó László (szerk.) (2006): Környezetmenedzsment. TYPOTEX, Budapest

Lamberton, Geoff (2005): Sustainability accounting - a brief history and conceptual framework. Accounting $F_{0}$ rum, 29, 7-26.

Loew, Thomas - Ankele, Kathrin - Braun, Sabine Clausen, Jens (2004): Significance of the CSR debate for sustainability and the requirements for companies. Future e.V. and Institute for Ecological Economy Research $\mathrm{GmbH}$, Berlin

Madarasiné Szirmai Andrea (2009): A pénzügyi kimutatások valóságtartalma a környezeti információk tükrében. Ph.D. Doktori értekezés, Budapest

Meadows, Donella H. - Meadows, Dennis L. - Randers, Jorgen - Behrens, William W. (1972): The Limits to growth: A report for the Club of Rome's Project on the Predicament of Mankind. New York

Mathews, M.R. (1997): Twenty-five years of social and environmental accounting research: Is there a silver jubilee to celebrate? Accounting, Auditing and Accountability fournal, vol. 10., no. 4., 481-531.

Mathews, M.R. (2000): The Development of Social and Environmental Accounting Research 1995-2000. Discussion Paper Series, 205, Massey University, School of Accounting, Palmerston

Mullerat, Ramon (2010): International Corporate Social Responsibility: The Role of Corporations in the Economic order of the 21st Century. Kluwer Law International

Németh Patrícia (2006): A vállalati környezetvédelmi tevékenység szerepe a versenyképességben, a piaci sikerességben. Ph.D. értekezés, Budapest

Pál Tamás (2003): Számviteli rendszerek, speciális eljárások. Economix Kiadó, Miskolc

Parker, Lee D. (2005): Social and environmental accountability research $\mathrm{A}$ view from the commentary boxs. $A c$ counting, Auditing and Accountability fournal, vol. 18., no. 6., 842-860.

Perego, Paolo (2005): Environmental Management Control, An Empirical Study on the Use of Environmental Performance Measures in Management Control Systems. Ponsen and Looijen BV, Wageningen

Perry, Martin - Sheng, Teng Tse (1999): An overview of trends related to environmental reporting in Singapore. Environmental Management and Health, vol. 10., no. 5. , 310-320.

Reyes, Maria Fatima (2002): The Greening of Accounting:
Putting the Environment onto the Agenda of the Accountancy Profession in the Philippines. Environmental Management Accounting: Informational and Institutional Developments, 215-220.

Riahi-Belkaoui, Ahmed (2005): Accounting Therory, 5th ed., Thomson, London

Schaltegger, Stefan - Burritt, Roger (2000): Contemporary Environmental Accounting: Issues, Concepts and Practice. Greenleaf

Schaltegger, Stefan - Burritt, Roger L. (2010): Sustainability accounting for companies: Catchphrase or decision support for business leaders? Fournal of World Business, 45, 375-384.

Senge, S.V. (1993): Accounting for the environment: an analysis of issues. Ohio CPA fournal, vol. 52., no. 1., 33-42.

Staib, Robert (2005): Environmental Management and Decision Making for Business. PALGRAVE MACMILLAN

Ván Hajnalka (2012a): A környezeti számvitel, mint a számviteli rendszer új kihívása. Pénzügyi Szemle, vol. 57., no. 4., 469-484.

Ván Hajnalka (2012b): Környezeti hasznok és kimutatásuk a környezeti vezetôi számvitelben. Doktori értekezés, Szeged

WCED (1987): Our Common Future, United Nations

Wildavsky, Aaron (1994): Accounting for the environment. Accounting, Organizations and Society, vol. 19., no. 4-5., 461-481.

Wilmshurst, Trevor - Frost, Geoff (2000): Corporate Environmental reporting: A Test of Legitimacy Theory. Accounting, Auditing and \& Accountability fournal, vol. 13., no. 1., 10-26.

2000. évi C. törvény a számvitelről

ecoloung.hu http://ecolounge.hu/rolunk/kedvenc-idezetek 